\title{
Serological and Molecular Epidemiology of Human Brucellosis in Mymensingh region Bangladesh
}

\author{
Md. Rasheduzzaman', Muhammad Akram Hossain², Shyamal Kumar Paul', Syeda Anjuman \\ Nasreen $^{3}$, Nazia Haque ${ }^{1}$, Ayenun Akter ${ }^{4}$, Sikdar Muhammadullah $^{5}$, Md. Humayun Kabir ${ }^{5}$, \\ Suraiya Jahan Sonia ${ }^{6}$, Salma Ahmed ${ }^{1}$
}

${ }^{1}$ Department of Microbiology, Mymensingh medical college, Mymensingh, Bangladesh, ${ }^{2}$ Department of Microbiology and Mycology, National institute of preventive and social medicine (NIPSOM), Bangladesh, ${ }^{3}$ Department of Microbiology, Sheikh Hasina Medical College, Jamalpur, Bangladesh, ${ }^{4}$ Department of Gynae and Obstetrics, Mymensingh medical college, Mymensingh, Bangladesh, ${ }^{5}$ Department of radiology and imaging \& Department of Microbiology, National Institute of kidney diseases and Urology, Bangladesh, ${ }^{6}$ Department of Physiotherapy and Occupational Therapy, National Institute of Traumatology and Orthopaedic Rehabilitation (NITOR), Bangladesh.

\begin{abstract}
Brucellosis is a major Bacterial Zoonotic disease worldwide. More than 500,000 new cases are reported globally every year with the annual incidence rates varying widely from $<2$ to $>500$ per 1000,000 population among different region of the world. This cross sectional descriptive study was carried out in the department of microbiology, Mymensingh medical college, Mymensingh, Bangladesh from $1^{\text {st }}$ January to 31 December 2017, on total 600 patients of PUO with or without occupational exposure. Blood was taken as sample, serum was separated and screening test was done by Brucella specific latex agglutination test from all collected samples. A Titer of $\geq 1: 160$ was taken as positive. ICT, PCR and real time PCR were done from all screening positive samples. Among the study population 65.83\% (395/600) were male and $34.17 \%$ (205/600) were female. The sero prevalence of Human Brucellosis was found 13.33\% (40/300) and 5\% (15/300), respectively in risk and non risk group of population. Out of 55 Brucella specific latex agglutination test positive samples $27.27 \%$ (15/55) were ICT positive, 5.45\% (3/55) were PCR positive and 3.64\% (2/55) were real time PCR positive. No ICT, PCR or Real time PCR cases were found from sero negative samples. Among the ICT positive cases 86.67\% (13/15) from risk group and $13.33 \%$ (2/15) from non risk group of study population. Among the 3 PCR positive cases $13.33 \%$ (2/15) were from ICT positive cases and $2.5 \%$ (1/40) from ICT negative cases. All PCR and Real time PCR positive cases were found in risk group of study population. No reliable data for Human Brucellosis is available in our country. However the present study revealed that a considerable number of Human Brucellosis is present in risk group as well as non risk group of population in both rural and urban area in Mymensingh district of Bangladesh. In our country we use only Brucella specific latex agglutination test for diagnosis of human Brucellosis. It is a non specific test and gives many false positive results. So it is necessary to introduce newer tests with higher sensitivity and specificity which will help to diagnose the disease rapidly and more accurately.
\end{abstract}

\section{Introduction}

Brucellosis is a worldwide reported zoonotic and occupational disease in farmers, veterinarians, slaughter house workers, animal handlers and meat inspectors ${ }^{1}$. It is caused by bacteria belonging to genus Brucella. They are small gram-negative, intracellular, non spore forming, non capsulated cocco-bacilli2. Brucellosis is a very old zoonotic disease and recent evidence showed that it was recognized as a clinical entity from the times of Crimear

Correspondence:

Dr. Md. Rasheduzzaman (MBBS)

Email: dr.rashed.prince@gmail.com war $^{3}$. The responsible micro-organism was isolated by David Bruce in 1887 from the spleen of a soldier who died from the disease ${ }^{4}$. There are six known species of Brucellae including B.melitensis, B.abortus, B.sius, B.canis. B.ovis, B.neotomae are identified at present ${ }^{5}$. According to World Health Organization every year more than 500,000 new cases are reported with the annual incidence rates varying widely from $<2$ to $>500$ per 1000,000 population among different region of the world ${ }^{1,6}$. The disease remains endemic in many regions of the world including the Eastern Mediterranean basin, The Middle East, The Arabian 
peninsula, Mexico, Central and South America, Central Asia, and the Indian subcontinent ${ }^{7}$. International travelers visiting Brucella endemic region are at risk of infection ${ }^{1}$. There are sporadic reports of prevalence of Human Brucellosis in Bangladesh and the true incidence of Brucellosis is not known. Serological tests done among cattle handlers of some villages in Bangladesh showed that the prevalence is in between 6-12.8 \% .

The most important way for transmission of Brucella to human is consumption of unpasteurized milk and milk products, contact with meat and blood of infected livestock, skin cuts, breathing dust contaminated with feces and urine of the infected animal. Transmission of the disease from Human to Human has rarely been happening but it may be transmitted through sexual intercourse (sperm), blood transfusion, bone marrow transplantation, shared drug needles among the addicted, intrauterine transfusion through the placenta and breast milk ${ }^{9,10}$.

Human Brucellosis is a debilitating illness characterized by fever (78\%), arthralgia (65\%), myalgia (47\%), and back pain (45\%). Hepatomegaly (23\%), spleenomegaly $(26 \%)^{11}$. Human Brucellosis is often misdiagnosed or under diagnosed due to overlapping clinical manifestations with many other bacterial infections. It is one of the causes of fever of prolonged duration in endemic areas and one of the important causes of pyrexia of unknown $\operatorname{origin}^{12}$.

The laboratory diagnosis of Human Brucellosis is based on microbiological, serological, or molecular methods, each having its own advantages and disadvantages ${ }^{13}$. Many serological tests such as rose bengal plate test (RBPT), complement fixation test (CFT) and serum agglutination test (SAT), Coombs test, ELISA are used for the diagnosis of Human Brucellosis ${ }^{14}$ but isolation of pathogen from blood culture remains the gold standard ${ }^{15}$. The molecular diagnosis of Human Brucellosis can be performed using genus specific polymerase chain reaction $(\mathrm{PCR})^{16}$, molecular assay targeting the bcsp31 gene coding for a $31 \mathrm{kDa}$ immunogenic outer membrane protein conserved among all Brucella spp are the most common molecular targets in clinical applications ${ }^{13}$ in comparison to PCR. Real time PCR is a technique for determination and quantification of nucleic acid ${ }^{17}$.

\section{Materials and methods}

This cross sectional descriptive type of study was carried out in the Department of Microbiology, Mymensingh medical college, Mymensingh, Bangladesh, On patients suffering from pyrexia of unknown origin who were attending at outpatient and inpatient department of Mymensingh medical college hospital from 01/01/2017 to $31 / 12 / 2017$. Total 600 (six hundreds) patients of either sex (300 from risk group/occupationally exposed and 300 from non risk group) were included in this study. $10 \mathrm{ml}$ Whole blood was collected aseptically from each patient of which $5 \mathrm{ml}$ were stored in- $20^{\circ} \mathrm{C}$ for PCR and Real time PCR and serum were separated from rest of blood and used for Brucella specific latex agglutination test and ICT.

\section{Laboratory procedure}

At first screening test (Brucella specific latex agglutination test) were done with all collected samples and Titer $\geq$ 1:160 were consider as screening positive ${ }^{18}$. The screening positive samples were then tested for ICT, PCR and real time PCR. The Brucella specific latex agglutination test (Spinreact SA/SAU. ctra Santa calona. 7E.17176 SA NT ESTEVE 1E BAS (G1) Spain) was performed on each sample according to the manufacturer's instructions. Brucella IgM/IgG LFA is an immune chromatographic lateral flow assay (one diagnostics, 1090HA, Amsterdam, The Netherlands). The assay was intended to be used as an aid in the sero diagnosis of Brucellosis. The Brucella $\operatorname{IgM} / \operatorname{IgG}$ LFA consists of two devices, one for the detection of specific IgM antibodies and one for the detection of specific IgG antibodies and the test were done according to the manufacturer's instructions.

\section{Polymerase chain reaction (PCR)}

Detection of Brucella genome specific gene encoding outer membrane protein by PCR from blood was performed by using standard protocol with specific primer ${ }^{1}$. The primers and reagent were purchased from Sigma Aldrich co (St. Louis. MO, USA) The reaction mixture 25 $\mu \mathrm{l}$ consisted of $12.5 \mu \mathrm{l}$ of ready mix taq buffer with $\mathrm{Mgcl}_{2}$, (Sigma Aldrich, co, St. Louis, MO, USA), $0.5 \mu$ l forward primer $(10 \mathrm{pmole} / \mu \mathrm{l}), 0.5 \mu \mathrm{l}$ reverse primer $(10 \mathrm{pmole} /$ $\mu \mathrm{l}), 10 \mu \mathrm{l}$ of nuclease free water, To this mixture $1.8 \mu \mathrm{l}$ of template DNA was added.

\section{Protocol of thermal cycle}

Initial Denaturation at $95^{\circ} \mathrm{C}$ for 3 minutes

Denaturation at $95^{\circ} \mathrm{C}$ for 45 seconds

Primer annealing at $60^{\circ} \mathrm{C}$ for 45 second
Extension at $72^{\circ} \mathrm{C}$ for 2 minutes and 35 cycles (1)

Final extension at $72^{\circ} \mathrm{C}$ for 10 minutes 


\section{Primer used for PCR}

The molecular diagnosis of Human Brucellosis can be performed using genus specific primers by polymerase chain reaction $(\mathrm{PCR})^{16}$; molecular assay targeting the bcsp31 gene coding for a 31-kDa immunogenic outer membrane protein conserved among all Brucella spp are the most common molecular targets in clinical applications ${ }^{13}$.

Brucella specific $31 \mathrm{KDa}$ antigen specific primers $^{13}$

\begin{tabular}{|c|l|c|}
\hline Prime name & \multicolumn{1}{|c|}{ Sequence of primer } & Product size \\
\hline B4 & $\begin{array}{l}\text { 5'-TGGCTCGGTTGCCA- } \\
\text { ATATCAA-3' }\end{array}$ & \multirow{2}{*}{223 bp } \\
\hline B5 & $\begin{array}{l}\text { 5'-CGCGCTTGCCTTTC- } \\
\text { AGGTCTG-3' }\end{array}$ & \\
\hline
\end{tabular}

\section{Visualization and documentation}

The PCR products were run in $1.5 \%$ agarose gels stained with ethidium bromide and visualized under the UV transilluminator and photographs was taken by using digital camera.

\section{Interpretation}

Samples were score as positive when a PCR product of $223 \mathrm{bp}$ in case of $31 \mathrm{KDa}$ antigen genes could be detected in PCR.

\section{Real time PCR}

To detect Brucella spp by real time PCR from samples we used geneaid, genomic DNA purification kit for whole blood DNA isolation and purification ${ }^{19}$.

\section{Programming the real time PCR instrument ${ }^{19}$}

1) Select the filter pairs to be used (FAM and HEX).

2) Identification of unknown samples, positive and negative control.

3) Select the correct thermal protocols.

\section{Protocol of thermo cycler ${ }^{19}$}

1) Initial denaturation for activation the hotstar Taq DNA polymerase at $95^{\circ} \mathrm{C}$ for 12.30 minutes.

2) Denaturation at $97^{\circ} \mathrm{C}$ for 00.30 minutes.

3) Annealing and synthesis at $54^{\circ} \mathrm{C}$ for 1.30 minutes.

4) Terminal hold at $22^{\circ} \mathrm{C}$ for 5 minutes.

\section{(Point 2 and 3 run for 50 cycles)}

Result analysis: After the end of program, the graphics were seen. In negative control it was running along with the bottom and for positive control it gave a curve in the soft ware graphics.

\section{Results}

Table-1 Age and sex distribution of total study population $(\mathrm{n}=600)$.

Parenthesis indicates percentage

Table 1: Showing the total distribution of study population regarding age and sex. Among the study population $65.83 \%$ (395/600) were male and $34.17 \%$ (205/600) were female. Majority of the study population $49.17 \%$ $(295 / 600)$ were in the age group of $20-40$ years

\begin{tabular}{|c|c|c|l|}
\hline $\begin{array}{l}\text { Age distribution } \\
\text { years })\end{array}$ & Male & Female & Total \\
\hline$<20$ & $105(68.63 \%)$ & $48(31.37 \%)$ & $153(25.5 \%)$ \\
\hline $20-40$ & $180(60.02 \%)$ & $115(38.98 \%)$ & $295(49.17 \%)$ \\
\hline $41-60$ & $80(76.19 \%)$ & $25(23.81 \%)$ & $105(17.5 \%)$ \\
\hline$>60$ & $30(63.83 \%)$ & $17(36.17 \%)$ & $47(7.83 \%)$ \\
\hline Total & $395(65.83 \%)$ & $205(34.17 \%)$ & $600(100 \%)$ \\
\hline Ratio & \multicolumn{3}{|c|}{ Male: Female $=1.93: 1$} \\
\hline
\end{tabular}

Table 2: Result of Brucella specific latex agglutination test in risk and non risk group of study population

\begin{tabular}{|c|c|c|c|c|c|c|}
\hline \multirow[t]{2}{*}{ Titer } & \multicolumn{2}{|c|}{ Risk group } & \multirow{2}{*}{$\begin{array}{l}\text { cumulative } \\
\text { percentage }\end{array}$} & \multicolumn{2}{|c|}{ Non risk group } & \multirow{2}{*}{$\begin{array}{l}\text { cumulative } \\
\text { percentage }\end{array}$} \\
\hline & $\begin{array}{l}\text { no of } \\
\text { cases }\end{array}$ & percentage & & $\begin{array}{l}\text { no of } \\
\text { cases }\end{array}$ & percentage & \\
\hline $1: 20$ & 115 & $38.33 \%$ & -- & 155 & $51.67 \%$ & -- \\
\hline $1: 40$ & 80 & $26.67 \%$ & -- & 105 & $35 \%$ & -- \\
\hline $1: 80$ & 65 & $21.67 \%$ & -- & 25 & $8.33 \%$ & -- \\
\hline 1:160 & 36 & $12 \%$ & \multirow[t]{2}{*}{$13.33 \%$} & 15 & $5 \%$ & \multirow[t]{2}{*}{$5 \%$} \\
\hline $1: 320$ & 04 & $1.33 \%$ & & & -- & \\
\hline Total & 300 & & & 300 & & \\
\hline
\end{tabular}

Table 2: showing the result of Brucella specific latex agglutination test in both group of study population. In risk group $12 \%(36 / 300)$ and $1.33 \%(4 / 300)$ having a titer of 1:160 and 1:320 respectively, the cumulative percentage were $13.33 \%$ and in non risk group 5\% (15/300) population has a titer of 1:160 . 
Table 3: Distribution of ICT positive cases in latex agglutination test positive cases $(\mathrm{n}=55)$

\begin{tabular}{|c|c|c|}
\hline Group & ICT positive & ICT negative \\
\hline Risk $(\mathrm{n}=40)$ & $13(32.50 \%)$ & $27(67.5 \%)$ \\
\hline Non Risk $(\mathrm{n}=15)$ & $02(13.33 \%)$ & $13(86.67 \%)$ \\
\hline Total $(\mathrm{n}=55)$ & $15(27.27 \%)$ & $40(72.73 \%)$ \\
\hline
\end{tabular}

Table 3: shows the distribution of ICT positive cases among the Brucella specific latex agglutination test positive cases. Total 15(27.27\%) cases were ICT positive. Among them 13(32.5\%) were from risk group and $(13.33 \%)$ from non risk group of study population.

Table 4: Distribution of PCR positive cases among the Brucella specific latex agglutination test positive cases in both group of study population $(\mathrm{n}=55)$

\begin{tabular}{|c|c|c|}
\hline Group & PCR positive & PCR negative \\
\hline Risk group $(n=40)$ & 03 & 37 \\
\hline Non risk group $(n=15)$ & 00 & 15 \\
\hline Total $(n=55)$ & $03(5.45 \%)$ & $52(94.55 \%)$ \\
\hline
\end{tabular}

Table 4 : shows the distribution of PCR positive cases among the Brucella specific latex agglutination test positive cases. Total 5.45\% (3/55) cases were found PCR positive; all PCR positive cases were found in risk group and no cases were found positive in non risk group of study population.

Table 5: Real time PCR positive cases among the PCR positive and PCR negative cases

\begin{tabular}{|c|c|c|}
\hline Case & Real time PCR positive & Real time PCR negative \\
\hline PCR positive $(n=3)$ & 02 & 01 \\
\hline PCR negative $(n=52)$ & 00 & 52 \\
\hline Total $(n=55)$ & $02(3.64 \%)$ & $53(96.36 \%)$ \\
\hline
\end{tabular}

Table 5: showing the distribution of real time PCR positive cases among the PCR positive and PCR negative cases. Out of 55 cases $3.64 \%$ (2/55) were real time PCR positive. No Real time PCR positive cases were found from PCR negative cases. All PCR and Real time PCR positive cases were found in risk group of study population.

\section{$12345 \quad 6789101112131415161718$}

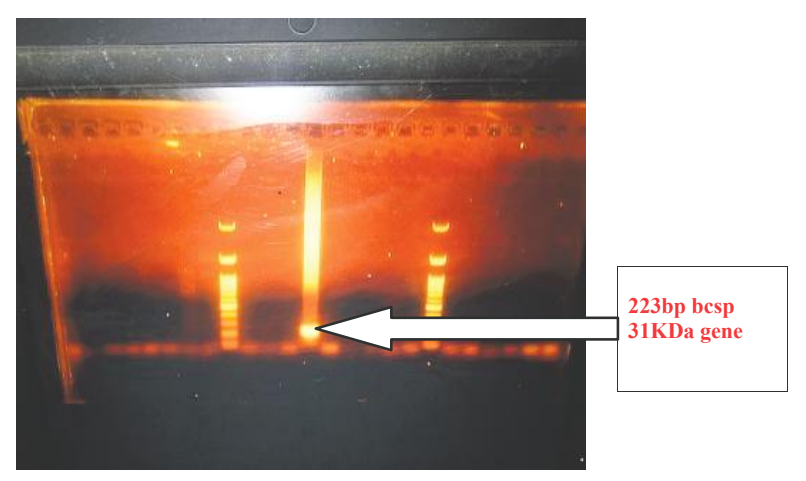

Figure 1: showing the PCR product of 31 KDa outer membrane gene

\section{Discussion}

In developing countries, Sub Saharan countries and African countries, Brucellosis is a major bacterial zoonotic disease found in human and domestic live stock. this affects the poor people livelihood by affecting their domestic live stock and thus causing them to compromise their health, survival and economic status ${ }^{20}$. In practice blood culture is positive in 10\%-30\% of Human Brucellosis cases and remainder is diagnosed serologically and by molecular methods ${ }^{21}$. Although no single test provides $100 \%$ sensitivity and specificity, a variety of serological tests and molecular tests have been applied for diagnosis of Human Brucellosis. In the present study majority of the cases $49.17 \%$ (295/600) were in the age group between $20-40$ years and total $65.83 \%(395 / 600)$ were male and $34.17 \%(205 / 600)$ were female. Male female ratio is $2: 1$ (table 1). The predominance of study population in age group (20-40yrs) and male was due to people in this age group being more active and as there are the main earning member of the family in our society. So they have more chance to occupational exposure ${ }^{4}$. The sero prevalence of Brucellosis by Brucella specific latex agglutination test in risk group was $13.33 \%(40 / 300)$ and non risk group $5 \%(15 / 300)$ respectively (Table-2). Some other study in our country showed that the sero prevalence of Brucellosis were 6 to $12.8 \%{ }^{8}$ in risk group. The increased prevalence rates in risk group of population may be due to occupational contact with domestic animal and lack of personal hygiene. The prevalence of Brucellosis by using $\operatorname{IgM} / \mathrm{IgG}$ (ICT) kit was $27.27 \%$ (15/55) (table-3). All the positive cases were found positive by IgM kit. No IgG kit were found positive. This indicates the cases were acute or recent infection. In a study at Borana and from Hamar, 
Ethiopia showed that $34.1 \%$ and $29.4 \%$ patients were sero positive for Brucellosis using Brucella immunoglobin M (IgM), lateral flow assay, which was almost similar to our current study. It appears, no data available regarding the use of ICT $\operatorname{IgM} / \mathrm{IgG}$ device for detection of Human Brucellosis in Bangladesh. In our present study we detected Brucella genome specific gene encoding outer membrane protein (LPS). (Table 4). Out of 55 sero positive samples $5.45 \%$ (3/55) were PCR positive. All positive cases were found in risk group. No cases from non risk group were found positive by PCR. The present study also detected the Brucella genus species DNA by real time PCR method; the findings of real time PCR from the sero positive cases were showed in (table 5). Out of 55 samples $3.64 \%(2 / 55)$ were found positive. The cut off value of real time PCR test were 0.849195 indicating a positive reaction in both situations. Out of 3 PCR positive cases 2 were real time PCR positive. The low prevalence of PCR and real time PCR positive cases in our country may be due to Brucellosis not being endemic in our country.

\section{Conclusion and Recommendations}

The present study revealed that a considerable number of Human Brucellosis is present in risk group as well as non risk group of population in both rural and urban area in Mymensingh district. More sensitive and specific test is required to diagnose the disease more rapidly and accurately, as latex agglutination test is non specific and gives many false positive results. Consequently Human Brucellosis should be included as a differential diagnosis in PUO cases especially in PUO with history of occupational exposure. Further study on the subject from different region of Bangladesh should be carried out in long scale to find out the true prevalence of the disease.

\section{Limitations}

Non availability as well as high cost of the reagent in local market limited the number of case in this study.

Time constrain, the study was done in a limited period of time.

\section{References}

1. Pathak AD, Dubal ZB, Doijad S, Raorane A, Rodrigues $\mathrm{S}$, Naik R, et al. Human brucellosis among pyrexia of unknown origin cases and occupationally exposed individuals in Goa Region, India. Emerging health threats journal. 2014 Jan 1;7(1):23846.
2. Nouri HR, Marashi MA, Rahimi MT, Baleghi Damavandi S, Ebrahimpour S. Diagnostic tests in human brucellosis. International journal of enteric pathogen. 2014 Jul 1;2(3):1-5.

3. Mantur BG, Amarnath SK. Brucellosis in India-a review. Journal of biosciences. 2008 Nov 1;33 (4):539-47.

4. Doganay M, Aygen B. Human brucellosis: an overview. International journal of infectious diseases. 2003 Sep 1;7(3):173-82.

5. Bamaiyi PH. Prevalence and risk factors of brucellosis in man and domestic animals: A review. International journal of one health. 2016;2:.29-34.

6. Surucuoglu S, Ural SE, Gazi HO, Kurutepe SE, Taskiran P, Yurtsever SG. Evaluation of real-time PCR method for rapid diagnosis of brucellosis with different clinical manifestations. Polish journal of microbiology. 2009;58(1):15.

7. Araj GF. Update on laboratory diagnosis of human brucellosis. International journal of antimicrobial agents. 2010 Nov 1;36:S12-7.

8. Rahman AA, Dirk B, Fretin D, Saegerman C, Ahmed MU, Muhammad N, et al. Seroprevalence and risk factors for brucellosis in a high-risk group of individuals in Bangladesh. Foodborne pathogens and disease. 2012 Mar 1;9(3):190-7.

9. Mahmood TA, Mohammed SJ, Abbood WS, Mohammed SN, Hashim SM, Mohammed KG. Diagnostic and Epidemiologic Study of Human Brucellosis at Al-Najaf province, kufa. Journal for nursing sciences. 2016;6(2).

10. Kassiri H, Amani H, Lotfi M. Epidemiological, laboratory, diagnostic and public health aspects of human brucellosis in western Iran. Asian pacific journal of tropical biomedicine. 2013 Aug 1;3(8):589-94.

11. Badri AM, Mohamed SG. Sero-Prevalence and Molecular Detection of Brucellosis among Febrile Patients in West Darfur State, Sudan. Molecular biology. 2018;7(204):2.

12. Çiftçi E, İnce E, Doğru Ü. Pyrexia of unknown origin in children: a review of 102 patients from Turkey. Annals of tropical paediatrics. 2003 Dec 1;23(4): 259-63. 
13. Navarro E, Casao MA, Solera J. Diagnosis of human brucellosis using PCR. Expert review of molecular diagnostics. 2004 Jan 1;4(1):115-23.

14. Memish ZA, Almuneef M, Mah MW, Qassem LA, Osoba AO. Comparison of the Brucella Standard Agglutination Test with the ELISA IgG and IgM in patients with Brucella bacteremia. Diagnostic microbiology and infectious disease. 2002 Oct $1 ; 44(2): 129-32$.

15. Barbuddhe SB, Vergis J, Rawool DB. Immunodetection of Bacteria causing brucellosis. Methods in Microbiology. 2020 Jan 1;47:75-115.

16. Al Dahouk S, Nöckler K. Implications of laboratory diagnosis on brucellosis therapy. Expert review of anti-infective therapy. $2011 \mathrm{Jul}$ 1;9(7):833-45.

17. Wang Y, Wang Z, Zhang Y, Bai L, Zhao Y, Liu C,et al. Polymerase chain reaction-based assays for the diagnosis of human brucellosis. Annals of clinical microbiology and antimicrobials. 2014 Dec;13(1):1-8.
18. Sümer H, Sümer Z, Alim A, Nur N, Özdemir L. Seroprevalence of Brucella in an elderly population in mid-Anatolia, Turkey. Journal of health, population and nutrition. 2003 Jun 1:158-61.

19. Hassoon Al-Shabaa KF, Sami W, Al-Yasiri IK, Mansour H. Molecular detection of human brucellosis in iraqi population. Journal of advanced scientific research. 2016 Feb 1;7(1).

20. John K, Fitzpatrick J, French N, Kazwala R, Kambarage D, Mfinanga GS, et al. Quantifying risk factors for human brucellosis in rural northern Tanzania. PLOS one. 2010 Apr 1;5(4):e9968.

21. Young EJ. An overview of human brucellosis. Clinical infectious diseases. 1995 Aug 1;21(2):283-9. 